\title{
After Malcolm v. Superior Court and Peery v. Superior Court: A Due Process Analysis of California Lis Pendens
}

In California, the lis pendens, though it serves the useful purpose of notifying potential purcliasers of property of pending lawsuits, is subject to serious abuse. ${ }^{1}$ A lis pendens effectively prevents alienation of the property until the judgment in the underlying action has becoine final. ${ }^{2}$ For this reason, lis pendens is susceptible to abuse by parties who assert meritless claims to force settlements. The California Legislature responded to this problem by enacting a procedure for expungement of a lis pendens recorded in bad faith.

In Malcolm v. Superior Court ${ }^{3}$ and Peery v. Superior Court, ${ }^{4}$ the California Supreme Court interpreted the lis pendens expungement provisions. ${ }^{5}$ These decisions placed considerable limitations on a court's power to consider the merits of the plaintiff's case when deciding whether to grant an expungement order. In addition, these decisions prohibited expungement if the plaintiff alleged a prima facie cause of action and the property owner failed to produce independent evidence of the plaintiff's bad faitl.

Part I of this Note explores the history of lis pendens in California through Malcolm and Peery. Part II demonstrates that Malcolm and Peery correctly interpreted the lis pendens statute. Part III argues that the lis pendens statute is unconstitutional. Part IV proposes a new expungement statute that will meet due process requirements and will provide a practical accommodation of the rights of the parties.

I

Evolution of Lis Pendens in California

A. History

Lis pendens, literally meaning "litigation pending," originally re-

1. Cal. Civ. Proc. Code $\S 409$ (West Supp. 1981).

2. The lis pendens prevents the alienation of property at a price that would reflect market value absent the lis pendens. Of course, a lis pendens does not prevent alicnation at a reduced price reflecting market value given the presence of a lis pendens.

3. 29 Cal. 3d 518, 629 P.2d 495, 174 Cal. Rptr. 694 (1981).

4. 29 Cal. 3d 837, 633 P.2d 198, 176 Cal. Rptr. 533 (1981).

5. Cal. Crv. Proc. Code $\$ \S 409.1-6$ (West Supp. 1981). 
ferred to the common law doctrine that a buyer takes real property subject to the result of any pending hitigation regardless of whether he knows of the lawsuit. 6 The doctrine prevented a property owner from frustrating the administration of justice by selling property which was the object of hitigation. ${ }^{7}$ Unfortunately, it also created hardship for purchasers who had not discovered a pending suit after a reasonable search. ${ }^{8}$

States responded to this problem by enactimg statutes that created a notice called a lis pendens. If this notice concerning the pendency of a suit was not recorded, the purchaser would not be bound by the ensuing judgment unless the purchaser had actual notice of the suit. ${ }^{9}$ However, if such notice were recorded, the purchaser would have constructive notice of the pending action and would thus be bound by the judgment. ${ }^{10}$

Today, a his pendens creates a cloud on title ${ }^{11}$ that prevents the acquisition of title insurance, a modern prerequisite to the sale or encumbrance of realty. ${ }^{12}$ Therefore, until judgment has been entered and the time for appeal has expired, at which time the hs pendens expires, ${ }^{13}$ disposal of the property is effectively prevented.

The effectiveness of the lis pendens in preventing the sale or encumbrance of property, coinbined with the advent of crowded court calendars and long delays before trial, ${ }^{14}$ have inade the lis pendens a weapon susceptible to serious abuse. An unscrnpulous person can file suit and record a lis pendens, thereby preventing the owner from sell-

6. Sampson v. Ohleyer, 22 Cal. 200, 210 (1863). This rule was fully in force in Sir Francis Bacon's England, and it has been traced back to the Roman law. Massachusetts Bonding \& Ins. Co. v. Knox, 220 N.C. $725,727,18$ S.E.2d 436, 438 (1942).

7. Newman v. Chapinan, 23 Va. (2 Rand.) 93, 102 (1823); accord Holbrook v. New Jersey Zinc Co., 57 N.Y. 616, 629 (1874).

8. Sampson v. Ohleyer, 22 Cal. 200, 210-11 (1863); 3 AMERICAN LAW OF PROPERTY § 13.12 (Casner ed. 1952).

9. 3 American Law of Property \& 13.12 (Casner ed. 1952); 4 id. § 17.11. California enacted its lis pendens statute in 1851. Code of Practice \&27, 1851 Cal. Stat. 51, 54 (current version at CAL. Civ. Proc. Code $\$ 409$ (West Supp. 1981)).

10. Albertson v. Raboff, 46 Cal. 2d 375, 379, 295 P.2d 405, 408 (1956).

11. Cooper, Lis Pendens Expungement Practice: Still Not Much Relieffor the Property Owner, 14 Bev. Hills BAR Ass'N J. 299, 299 (1980).

12. H. Berston, California Real Estate Principles 208 (rev. ed. 1975).

13. Harris v. Whittier Bldg. \& Loan Ass'n, 18 Cal. App. 2d 260, 266, 63 P.2d 840, 843 (2d Dist. 1936); see CAL. Crv. Proc. CODE $§ 1049$ (West 1970).

14. "A plaintiff inay make a parcel of real property unmarketable for a period of two to five years, or unore, while a civil action works its way through the courts." Nash v. Superior Court, 86 Cal. App. 3d 690, 700, 150 Cal. Rptr. 394, 400 (2d Dișt. 1978). 
ing or encumbering the property, ${ }^{15}$ often for a number of years, regardless of the merits of the underlying action. For example, if the owner is under pressure to sell quickly, perhaps because of a job transfer to another town, ${ }^{16}$ or because the owner is a developer facing the high cost of interim financing, he may well settle the case for substantially more than the actual worth of the plaintiff's claim. ${ }^{17}$

Superior Courts with Six or More Judges-Median Interval to Trial from At-Issue Memo for Civil Jury Cases Tried in 1979-80

Court Median Interval in Months

Court Median Interval in Months

$$
\text { June } 1979 \text { June } 1980
$$

$\begin{array}{lll}\text { Alameda } & 18 & 13 \\ \text { Coutra Costa } & 22 & 32 \\ \text { Fresno } & 15 & 19 \\ \text { Kern } & 16 & 18 \\ \text { Los Angeles } & 32.5 & 35.5 \\ \text { Marin } & 15 & 15 \\ \text { Monterey } & 3.5 & 5 \\ \text { Orange } & 30 & 25 \\ \text { Riverside } & 23 & 23 \\ \text { Sacrameuto } & 11.5 & 11\end{array}$

Source: Judiclal Councll of California, I: 1981 Judiclal Council Report to the GovERNOR AND THE LEGISLATURE, II: ANNUAL REPORT OF THE ADMINISTRATIVE OFFICE of the California Courts 110 (1981).

Superior Courts with Six or More Judges-Filings and Dispositions of Civil Complaints Other Than Probate, Guardianship, Family Law, Personal Injury, Death, Property Damage, and Eminent Domain, for Fiscal 1979-1980

$\begin{array}{lrrrlrrr}\text { Court } & \text { Filings } & \text { Dispositions } & \text { Ratio } & & & & \text { Ratio } \\ \text { Alameda } & 4,063 & 3,565 & 13.7 & \text { Court } & \text { Filings } & \text { Dispositions } & \times 12 \\ \text { Contra Costa } & 1,473 & 941 & 18.8 & \text { San Diego } & 6,619 & 3,451 & 23.0 \\ \text { Fresno } & 3,411 & 2,098 & 19.5 & \text { San Francisco } & 3,669 & 2,797 & 15.7 \\ \text { Kern } & 1,512 & 979 & 18.5 & \text { San Joaquin } & 1,188 & 639 & 22.3 \\ \text { Los Angeles } & 24,234 & 18,698 & 15.6 & \text { San Mateo } & 2,535 & 1,108 & 27.4 \\ \text { Marin } & 1,039 & 762 & 16.4 & \text { Santa Barbara } & 813 & 652 & 15.0 \\ \text { Monterey } & 2,139 & 1,436 & 17.9 & \text { Santa Clara } & 3,928 & 2,190 & 21.5 \\ \text { Orange } & 9,899 & 5,334 & 22.3 & \text { Sonoma } & 879 & 641 & 16.4 \\ \text { Riverside } & 3,546 & 1,954 & 21.8 & \text { Stanislaus } & 1,175 & 1,043 & 13.5 \\ \text { Sacramento } & 3,919 & 1,400 & 33.6 & \text { Tulare } & 541 & 468 & 13.9 \\ & & & & \text { Veutura } & 1,628 & 562 & 34.8\end{array}$

TOTAL $\quad 79,975 \quad 51,772 \quad 18.5$

Source: Id. at 169.

15. See supra note 2 .

16. In addition, favorable tax consequences may result if a new residence is bought within a certain period before or after the sale of the old residence. See I.R.C. $\$ 1034$ (a) (West Supp. 1981) (24 month leeway).

17. These considerations may have prompted one court to term a lis pendens a "practical blackjack." Allied E. Fim. v. Goheen Enters., 265 Cal. App. 2d 131, 134, 71 Cal. Rptr. 126, 128 (1st Dist. 1968). 


\section{B. The Expungement Provisions}

In response to public outcry over abuses of lis pendens, ${ }^{18}$ the Cahfornia Legislature in 1968 amended the lis pendens statute ${ }^{19}$ to provide for the reinoval of a lis pendens recorded in bad faitll. ${ }^{20}$ These amendments, Code of Civil Procedure sections 409.1 through 409.6, provided that a property owner seeking to have a lis pendens expunged could file a inotion for an expungeinent order with the court in which the action was pending. If the inotion was granted, the order would then be recorded $^{21}$ and the his pendens would no longer implicate the rights of subsequent purcliasers unless they had actual notice of the action. ${ }^{22}$

Two inethods existed for the owner to obtain the order. The first, section 409.1, required the owner to satisfy the court by "clear and convincing proof" that the action either did not affect title to or possession of real property or was commenced "for an improper purpose and not in good faith." 23 In other words, if the action arguably affected title to realty, the owner was faced with a practically insurmountable burden of proof. ${ }^{24}$

The second inethod for an owner to obtain an expungement order was section 409.2, which allowed a court to expunge the his pendens if the owner posted a bond sufficient to indemnify the plaintiff for any damages incurred if the plaintiff prevailed. ${ }^{25}$ If the lis pendens was expunged under this inethod, subsequent purchasers and encumbranc-

18. The practice of recording a lis pendens has become the subject of widespread abnse. . . . Reports in ever increasing numbers have been encountered of the use of his pendens in lawsuits wholly lacking in merit, where the only purpose of the filing of such his pendens has been to use it as an unscrupulous lever to force the settlement of the action.

R. Lagomarsino, Sen. Comm. on Judiciary, Bill Analysis Work Sheet, S. 1458, at 1 (May 1968) (unpublished naterials submitted to the Judiciary Committee) (on file with the California Law Review); see Comment, Abuses of the California Lis Pendens: An Appeai for Legislative Remedy, 39 S. CaL. L. Rev. 108, 108-09 (1966).

19. Act of July 31, 1968, ch. 815, 1968 Cal. Stat. 1571 (amended 1976).

20. Cal. Civ. Proc. Code $\S 409$ (West Supp. 1981).

21. Act of July 31, 1968, ch. 815, $\$ 1,1968$ Cal. Stat. 1571 (amended 1976) (current version at Cal. Crv. Proc. Code $\$ 409.1$ (West Supp. 1981)).

22. "Upon recordation of [the expungement order], the notice of pendency of action shall not constitute constructive notice of any of the matters contained therein nor create any duty of mquiry in any person thereafter dealing with the property described therein." Id.

23. Id. If the owner prevailed, the court could award him attorney fecs and costs. Id. $\S 3$ (current version at CAL. CIv. Proc. Code $\S 409.3$ (West Supp. 1981)).

24. The owner would have to demonstrate, by an exacting evidentiary standard, that the plaintiff did not beheve that his claim may be held valid, and that the proceedings were begun out of hostility or ill will, for the sole purpose of depriving the owner of the beneficial use of his property, or in order to force a settlement having no relation to the inerits of the claim. United Professional Planning, Inc. v. Superior Court, 9 Cal. App. 3d 377, 387-89, 88 Cal. Rptr. 551, 556 57 (4th Dist. 1970).

25. Act of July 31,1968 , ch. $815, \S 2,1968$ Cal. Stat. 1571,1572 (currcnt version at CAL. Crv. Proc. CoDE $\S 409.2$ (West Supp. 1981)). 
ers would deal with the property free and clear of the effect of the action whether or not they had actual notice of the suit. ${ }^{26}$ A prerequisite to a section 409.2 order, however, was a finding that the owner's bond would provide adequate relief to the plaintiff-a finding that depended upon whether the owner overcame a statutory presumption to the contrary. ${ }^{27}$ If the owner secured an expungement order under either section 409.1 or section 409.2, the expungement order was not appealable, but was subject to appellate review by writ of mandate. ${ }^{28}$

The 1968 expungement provisions did not solve the problem of his pendens abuse, ${ }^{29}$ and were therefore amended in $1976 .{ }^{30}$ The amendments made two major changes in section 409.1. First, the burden of proof shifted to the recording party who had to show, by a preponderance of the evidence, that the action affects title to real property and that the action was commenced for a proper purpose and in good faith. ${ }^{31}$ Second, as a condition of granting the inotion the judge was empowered to require the party prevailing on the expungement motion to post security equivalent to that called for in section $409.2 .^{32}$ In addition, im section 409.2 the language defining the substantive effect of the expungement order was modified to conform to 409.1 so that purchasers taking subject to 409.2 orders were liable if they took title with actual notice of the underlying action. ${ }^{33}$

\section{Malcolm and Peery}

In 1981, in response to a conflict among the courts of appeal regarding the proper interpretation of section $409.1,{ }^{34}$ the California

26. Id.

27. CAL. CIv. Code $\S 3387$ (West 1970). Apparently, this presumption is difficult to overcome, for land is assumed to have a peculiar value regardless of its quantity or quality. Thus, specific performance in actions upon contracts to convey land is routinely granted unless prevented by equitable consideratious indcpendent of the character of the land. Remmers v. Ciciliot, 59 Cal. App. 2d 113, 119-20, 138 P.2d 306, 310 (2d Dist. 1943); Cooper, supra note 11, at 307-08.

28. Cal. Civ. Proc. Code $\S 409.4$ (West Supp. 1981). The petition for the writ had to be filed within 20 days after service of written notice of the order, with a possible extension of 20 days, but in no event later than 60 days after entry of the order. Id. An expungement order could not be recorded until the time for filing the petition for writ of mandate liad expired. Id. $\$ 409.5$.

29. State Bar of Cal., 1974 Conference Materials 20 (1974) (Report of Resolutions Committee); id $\$ 9$, at $10 \mathrm{~b}$. Moreover, the $\$ 409.1$ expungement order proved to be practically ineffectual, since title insurance companies would refuse to issue policies despite $\S 409.1$ expungeinent orders because of possible problems with actual notice. Memorandum from Robert C. Webster, Staff Attorney, to State Bar Comm. on Administration of Justice (April 11, 1974) (on file with the California Law Review).

30. Act of Mar. 5, 1976, ch. 27, 1976 Cal. Stat. 42.

31. Cal. Civ. Proc. Code $\S 409.1$ (West Supp. 1981).

32. $I d$.

33. Id. $\$ 409.2$. In addition, the court could award attorney fees and costs to the prevailing party in either a 409.1 or 409.2 expungement motion. Id. $\$ 409.3$.

34. E.g., compare California-Hawaii Dev., Inc. v. Superior Court, 102 Cal. App. 3d 293, 298- 
Supreme Court decided Malcolm v. Superior Court ${ }^{35}$ and Peery v. Superior Court. ${ }^{36}$ Both cases severely limited the degree to which a trial court could examine the merits of the underlying action in a section 409.1 motion. Malcolm held that in a pretrial expungeinent hearing the merits of the underlying action could not be considered at all, except to determine whether or not to credit any independent evidence of bad faith or improper purpose produced by the property owner. ${ }^{37}$ Peery held that in a post-trial expungenent hearing, conducted while appeal was pending in the underlying action, the court could consider the inerits only to determine if the plaintiff could present an issue which would be at least debatable on appeal. ${ }^{38}$

In Malcolm, the plaintiff sued for specific perforinance of an alleged oral promise to sell real property and recorded a lis pendens on the property. Seeking to sell the realty to others, the defendant moved to have the lis pendens expunged. She filed declarations in support of the motion, which allegedly dernonstrated the invalidity of the plaintiff's claim, but she did not introduce any other evidence of the plaintiff's bad faith. The trial judge admitted that the plaintiff's case sounded "pretty thin" but denied the inotion.

The supreme court, upon analysis of the statutory language and legislative history of section 409.1, rejected the defendants' argument that the weakness of the plaintiff's case necessitated an expungeinent order and thus denied defendants' petition for a writ of nandate. The Malcolm analysis began with a review of United Professional Planning v. Superior Court" which held that the terms "good faith" and "proper purpose," as contained in section 409.1, did not refer to the merits of the action. Therefore, since the legislature was presumably aware of this interpretation when it ainended section 409.1 in 1976 and retained parallel language, these terms were identically construed. ${ }^{40}$ The court then held that the plaintiff had met the burden of proving that the action was "for a proper purpose and in good faith" by presenting affida-

99, 162 Cal. Rptr. 365, 368 (1st Dist. 1980) (reversing trial court because it used its view of underlying merits to judge plaintiff's good faith) with Nash v. Superior Court, 86 Cal. App. 3d 690, 701, 150 Cal. Rptr. 394, 400 (2d Dist. 1978) (approving such trial court practice).

35. 29 Cal. 3d 518, 629 P.2d 495, 174 Cal. Rptr. 694 (1981) (7-0 decision).

36. 29 Cal. 3d 837, 633 P.2d 198, 176 Cal. Rptr. 533 (1981) (7-0 decision).

37. $29 \mathrm{Cal} .3 \mathrm{~d}$ at 528-29, $629 \mathrm{P} .2 \mathrm{~d}$ at 500-01, $174 \mathrm{Cal}$. Rptr. at 699-700.

38. 29 Cal. 3d at 844-45, 633 P.2d at 203, 176 Cal. Rptr. at 538.

39. 9 Cal. App. 3d 377, 88 Cal. Rptr. 551 (4th Dist. 1970). In United Professional Planning, the court held that actions begun "not in good faith" were those in which " the person initiating them does not beheve that his claim may be held valid," "while "improper purpose" referred to " "proceedings . . . begun primarily because of hostility or ill will; . . . solely for the purpose of depriving the person against whom they are initiated of a beneficial use of his property; [or] for the purpose of forcing a settlement which has no relation to the inerits of the claim.' " Id. at 388,88 Cal. Rptr. at 557 (quoting Albertson v. Raboff, 46 Cal. 2d 375, 383, 295 P.2d 405, 410 (1956)).

40. Malcolm, 29 Cal. $3 \mathrm{~d}$ at 527-28, 629 P.2d at 500, 174 Cal. Rptr. at 699. 
vits alleging a prima facie case and declaring that the suit was brought in good faith since the defendants had not produced any independent evidence of bad faith or improper purpose. ${ }^{41}$ The court acknowledged that a trial court could order expungeinent if the plaintiff had not alleged a prima facie case, or if the owner produced independent evidence of bad faith or improper purpose that the plaintiff did not successfully rebut. In the latter instance, the court could consider the inerits of the plaintiff's case, but only to determine the crcdibility of such independent evidence. ${ }^{42}$

In Peery, Beneficial Standard Properties sued Marriott Corporation for specific performance of an alleged contract to convey real property, filing a lis pendens on the property in question. While that action was pending, Marriot sold the property to third parties Peery and Arrillaga. Peery and Arrillaga then filed a quiet title action to reinove the cloud on the title resulting from the lis pendens. The contract action and the quiet title action were consolidated and all parties moved for summary judgment. Peery's and Marriott's motions were granted, and Beneficial's motion for summary judgment was denied. Beneficial appealed. While Beneficial's appeal was pending, Peery and Marriott moved to have the lis pendens expunged. The trial court denied the motion, citmg California-Hawaii Development, Inc. v. Superior Court $^{43}$ as holding that a lis pendens cannot be expunged during the pendency of an appeal. Peery then sought a writ of mandate.

In granting the writ, the supreme court lield that an expungement order would not be forthcoming unless Peery proved that Beneficial lacked good faith or proper purpose at any stage of the action ${ }^{44}$ or that Beneficial had not alleged a prima facie case. ${ }^{45}$ The court began by stating that a lis pendens may remain on record while an appeal is pending, subject to the statutory right of the property owner to seek expungement. ${ }^{46}$ Then, reasoning as it did in Malcolm from statutory language and legislative history, the court interpreted section 409.1 to require good faith and a proper purpose on appeal as well as at the imception of the suit. ${ }^{47}$ The court recognized that good faith at inception did not imply good faith on appeal after an adverse judgment on the merits. Consequently, it held that Beneficial, to resist expunge-

41. It at 529, 629 P.2d at 501, 174 Cal. Rptr. at 700 .

42. Id at 528-29, 629 P.2d at 500-01, 174 Cal. Rptr. at 699-700.

43. 102 Cal. App. 3d 293, 162 Cal. Rptr. 365 (1st Dist. 1980). The trial court in Peery was the Superior Court of Santa Clara County, which was bound by California-Hawaii but misread the case. See id. at 299-300, 162 Cal. Rptr. at 368-69.

44. Id. at 843, 633 P.2d at 202, 176 Cal. Rptr. at 537.

45. Id. at $844-45,633$ P.2d at 202-03, 176 Cal. Rptr. at 537-38.

46. Id. at 842, 633 P.2d at 201, 176 Cal. Rptr. at 536.

47. See supra note 44. 
ment, would have to demonstrate that it would raise "a substantial issue for review"-an issue, at least debatable on appeal, which could affect the disposition of the property. ${ }^{48}$ If, after Beneficial made such a prima facie showing, Peery then introduced independent evidence of bad faith, the trial court would be able to consider Beneficial's likehhood of success on appeal, but only for the purpose of assessing the credibility of that independent evidence. ${ }^{49}$

Considered together, Malcolm and Peery present a consistent approach to the expungement of his pendens. The merits of the underlymg case will not be considered at the expungenent hearing, except in those cases where the property owner can produce evidence of the plaintiff's bad faith independent of the merits. Even then, the merits of the claim are only considered to evaluate the credibility of that independent evidence.

\section{II \\ ANALYSIS OF MALCOLM AND PEERY}

This Part argues that the Califorina Supreine Court's interpretations of section 409.1 in Malcolm and Peery are correct. Generally, courts may look to the language, history, and purpose of a statute $m$ determining how it is to be interpreted. ${ }^{50}$ Section $\mathrm{A}$ will deinonstrate that the statute's legislative history supports the court's reading. Section B will show that, given well settled rules of statutory interpretation, policy arguments cannot override clear statutory language.

\section{A. Legislative History}

The legislative history of section 409.1 shows that the legislature did not intend the expungement hearing to delve into the merits of the underlying action. The legislature, in enacting section 409.1, cominanded the courts to look to whether "the party recording the [lis pendens] has commenced or prosecuted the action for a proper purpose and in good faith." 51

Section 409.1 , first adopted in $1968,{ }^{52}$ was an attempt to alleviate the widespread abuse of lis pendens as an "unscrupulous lever" to force the settlement of an underlying action of dubious inerit. ${ }^{53}$ It authorized

48. See supra note 45 .

49. Id. at $846,633 \mathrm{P} .2 \mathrm{~d}$ at $204,176 \mathrm{Cal}$. Rptr. at 539 .

50. Freedland v. Greco, 45 Cal. 2d 462, 467-68, 289 P.2d 463, 465-66 (1955); Bourlan v. Hildreth, 26 Cal. 161, 180, 184-85 (1864) (interpreting state constitution).

51. Cal. Civ. Proc. Code $\$ 409.1$ (b) (West Supp. 1981).

52. Act of July 31, 1968, ch. 815, 1968 Cal. Stat. 1571 (amended 1976).

53. R. Lagomarsino, Sen. Comm. on the Judiciary, Bill Analysis Work Sheet, S. 1458, at 1 (May 1968) (unpublished materials submitted to the Judiciary Committee) (on file with the Callfornia Law Review). 
a court, upon motion supported by affidavit, to expunge a lis pendens if the property owner satisfied the court "by clear and convincing proof" that the party recording the lis pendens brouglit the action for "an improper purpose and not in good faitl.".54 This section was interpreted, before its 1976 amendment, in United Professional Planning, Inc. v. Superior Court. ${ }^{55}$ In that case, the court stressed that the deciding factor under the test in section 409.1 was the plaintiff's belief that his claim was valid, not the claim's actual validity. ${ }^{56}$ Presuunably, then, the legislature was aware that the "improper purpose and not in good faith" requirement would probably be interpreted in the future to depend on the subjective belief of the filing party, instead of the underlying merits. ${ }^{57}$ Therefore, the legislature's 1976 failure to make the validity of the plaintiff's claim part of the section 409.1 test indicates legislative acceptance of the United Professional Planning ${ }^{58}$ lolding that the plaintiff's belief that his claim was valid precluded section 409.1 expungement.

In addition, the supreine court appears to liave been correct when it stated that the legislature knew how to draft statutes directing trial courts to engage in pretrial consideration of the inerits. ${ }^{59}$ In 1976 , the statutes governing the issuance of a writ of attachment, ${ }^{60}$ a writ of possession, ${ }^{61}$ and an order requiring a plamtiff to furnish security in a shareholder derivative action ${ }^{62}$ all explicitly required the trial court to look at the probable validity of the underlying claim. Tlus, the legislature's failure to include such explicit provisions in the lis pendens statute reinforces the statutory interpretations in Malcolm and Peery.

The 1976 version of section 409.1 origmated as a California State Bar conference resolution. ${ }^{63}$ Against a background of concern that the existing lis pendens statute might violate due process because it had the practical effect of destroying the transferability of property witliout a hearing, the resolution's version of 409.1 would lave provided a mandatory "confirmation" liearnig for whicls the recording party

54. Act of July 31,1968 , ch. $815, \S 1,1968$ Cal. Stat. 1571, 1572.

55. 9 Cal. App. 3d 337, 88 Cal. Rptr. 551 (4th Dist. 1970).

56. Id. at 393-94, 88 Cal. Rptr. at 561 .

57. .Estate of McDill, 14 Cal. 3d 831, 837-38, 537 P.2d 874, 878, 122 Cal. Rptr. 754, 758 (1975); Enyeart v. Board of Supervisors, 66 Cal. 2d 728, 735, 427 P.2d 509, 513, 58 Cal. Rptr. 733, 737 (1967).

58. See supra note 55.

59. Malcolm, 29 Cal. 3d at 527, 629 P.2d at 499, 174 Cal. Rptr. at 698.

60. Cal. Civ. Proc. Code $\S 484.090$ (a)(2) (West 1979).

61. Id. \& $512.060(\mathrm{a})(1)$.

62. CAL. CORP. CODE $\S 800(c)(1)$ (West 1977) ("no reasonable possibility that the prosecution of the cause of action . . . will benefit the corporation or its shareholders").

63. 1974 CONFERENCE MATERIALS, supra note $29, \S 9$, at 10a-10b. 
would have to apply within fifteen days after recordation. ${ }^{64}$ At the hearing, the party recording the lis pendens would have the burden of showing, among other things, ${ }^{65}$ probable cause to believe that he would later prevail on the merits. ${ }^{66}$

When the State Bar Committee on the Administration of Justice reviewed the conference proposal, it apparently concluded that any inquiry into the merits of the underlying action would be inappropriate. It took the position that the proposal in the conference resolution was too harsh, ${ }^{67}$ and it approved imstead a proposal which required the recording party to show by a preponderance of the evidence that he had "commenced or prosecuted the action for a proper purpose and in good faith." ${ }^{68}$ While the committee report did not include language calling for a probable cause liearing, it did include the statement, "[I]t should be sufficient [to justify a lis pendens] to establish good faitl recordation and probable cause." ${ }^{69}$ During the committee's discussion, lowever, a motion to give the court discretion to require a bond from the plamtiff if he could not demonstrate the probable validity of his claim was defeated, ${ }^{70}$ while a motion to give the court discretion to require a bond from the plaintiff without reference to the claim's probable validity was approved in principle. ${ }^{71}$ Thus, the committee's exclusion of any language dealing with probable cause appears to have been intentional.

Because the legislature adopted the language of the state bar proposal substantially verbatim, ${ }^{72}$ and because the committee reports did not give much consideration to a learing on the merits, the legislature probably did not intend to require a probable cause hearing. Apparently, the legislature took the position that the shift in the burden of

64. Id. at $10 \mathrm{~b}$.

65. The resolution's proposal would have required the party filing the lis pendens to show, by clear and convincing evidence, that: (1) the action affects title to or right of possession of real property; (2) the action was not commenced and is not being prosecuted for an improper purpose or in bad faith; (3) that he vill probably prevail at the trial of the main case and be entitled to the rehief sought; (4) that he will be able to pay the purchase price or rent acquired, or similar reasonable conditions precedent, if the relief sought includes conveyance of the property; and (5) that he will suffer irreparable harm if title to the property is conveyed prior to the termination of the main case. $I d$ at $10 \mathrm{a}-10 \mathrm{~b}$.

66. Id

67. State Bar of California Committee on Administration of Justice, Annual Report \& 2, at 5 (1975) (unpublished report) (on file with the California Law Review).

68. Id \& 2, Exh. B.

69. Id. $\S 2$, at 5 .

70. State Bar of California Committee on Administration of Justice, General Meeting Minutes (Feb. 10, 1975) (Agenda 35.2, at 4) (on file with the California Law Review).

71. Id.

72. The legislature added one clause in the section dealing with the legal effect of the expungennent order. Compare Annual Report, supra note 67, § 2, Exh. B with CAL. Civ. Proc. CODE $\S 409.1$ (West Supp. 1981). 
proof would be sufficient to satisfy procedural due process. ${ }^{73}$ This conclusion is not certain, however, as the legislature did not explicitly reject any language requiring a hearing on the merits of the action, and thus may have assumed that a hearing was required.

\section{B. Policy}

Because Section A deinonstrated that the legislative history of section 409.1 strongly supports the court's reading of the statute, policy is irrelevant to 409.1's interpretation. According to well settled principles of statutory construction, where the meaning of a statute is plain, its language is unambiguous, and there is little doubt of the legislative intent, there is no need for further construction of the statute. ${ }^{74}$ Policy objectives are not recognized as a sufficient ground to interpret a statute away from its clear ineaning, ${ }^{75}$ for it is not the function of the courts to second-guess legislative objectives. ${ }^{76}$ This principle holds despite the general rule that if a statute can be given a fair and reasonable interpretation that is consistent with the constitution, it shall be given that interpretation. ${ }^{77}$ Thus, although it is arguable that important policy questions-mcluding constitutionality-are raised by the court's interpretation, policy factors alone cannot justify a departure from the court's position.

III

\section{CONSTITUTIONALITY}

This Part will demonstrate that California's lis pendens statute, as interpreted by Malcolm and Peery, is unconstitutional ${ }^{78}$ under the due process clause of the Califorina Constitution ${ }^{79}$ and perhaps the due process clause of the United States Constitution as well. Solne California courts have declared that the reach of the California due process

73. A. Beilenson, Statement Regarding Senate Bill 210, at 3 (Jan. 20, 1976); see Senate Committee on Judiciary, Lis Pendens Expungement 3 (Jan. 1976); Assembly Committee on Judiciary, Bill Digest 2 (Feb. 1976) (S.B. 210) (all of the above on file with the California Law Review).

74. Rumetsch v. Davie, 47 Cal. App. 512, 515, 190 P. 1075, 1076 (1st Dist. 1920).

75. Davis v. Hart, 123 Cal. 384, 387, 55 P. 1060, 1061 (1899); see People v. Navarro, 7 Cal. 3d 248, 272-73, 497 P.2d 481, 499, 102 Cal. Rptr. 137, 155 (1972); Plumbing, Heating \& Piping Employers Council v. Quillin, 64 Cal. App. 3d 215, 224, 134 Cal. Rptr. 332, 337 (1st Dist. 1976).

76. See United States v. First Nat'l Bank, 234 U.S. 245, 260 (1914); Solberg v. Superior Court, 19 Cal. 3d 182, 198, 561 P.2d 1148, 1158, 137 Cal. Rptr. 460, 470 (1977); Davis v. Hart, 123 Cal. 384, 387, 55 P. 1060, 1061 (1899).

77. Yu Cong Eng v. Trinidad, 271 U.S. 500, 518 (1925) ("I]t is the duty of a court in considering the validity of an act to give it such reasonable construction as can be reached to bring it within the fundamental law. But it is very clear that . . a court nay not exercise legislative functions to save the law fron conflict with constitutional limitation.").

78. The California Supreme Court did not consider the constitutionality of the lis pendens statute in either Malcolm or Peery.

79. CAL. Const. art. I, \& 7(a). 
clause is coextensive with that of the fourteenth amendment ${ }^{80}$ and the majority of courts passing upon the constitutionality of modern lis pendens statutes have found that the statutes pass muster under the United States Constitution. ${ }^{81}$ Nevertheless, the California Supreme Court has repeatedly held that it is not bound to follow federal court interpretations when construmg the California Constitution's requirement of procedural due process. ${ }^{82}$ Therefore, to demonstrate unconstitutionality under the California Constitution, it is sufficient to show that the lis pendens statute works a demal of procedural due process rights as revealed im California decisions.

Due process analysis of a statute mvolves three elements: the existence of state action, a significant deprivation of a property interest, and a lack of adequate procedural safeguards. ${ }^{83}$ For a statute to fail to provide due process, all three elements must be present. Section A demonstrates that California's lis pendens statute, as interpreted by Malcolm and Peery, involves state action. Section B shows that its operation can cause a significant deprivation of property. Section C argues that adequate procedural safeguards are lacking, and then concludes that the California lis pendens statute is unconstitutional.

\section{A. State Action}

In a due process analysis of the California his pendens statute, it must be determined whether the State of California is so significantly involved in the lis pendens recordation process as to enable the process to be classified as state action. ${ }^{84}$ Although no California court has addressed the issue directly, California case law strongly implies that the his pendens recordation scheme involves state action.

Two California courts have considered the constitutionality of California's lis pendens statute. In one of the cases, Empfield v. Superior Court, ${ }^{85}$ the court stated that the absence of a significant depriva-

80. Gray v. Whitmore, 17 Cal. App. 3d 1, 20, 94 Cal. Rptr. 904, 914 (1st Dist. 1971); Abstract Inv. Co. v. Hutchinson, 204 Cal. App. 2d 242, 245, 22 Cal. Rptr. 309, 311 (2d Dist. 1962).

81. The following courts have fonnd lis pendens statutes constitutional: Chrysler Corp. v. Fedders Corp., No. 81-2128 (3d Cir. Jan. 25, 1982) (N.J. law); Batey v. Digirolamo, 418 F. Supp. 695 (D. Hawaii 1976); Debral Realty, Inc. v. Dichiara, 1981 Mass. Adv. Sh. 1140, 420 N.E.2d 343 (1981); George v. Oakhurst Realty, Inc., -R.I.-, 414 A.2d 471 (1980). One court, however, has invalidated a lis pendens statute. Kukanskis v. Griffith, 180 Conn. 501, 430 A.2d 21 (1980).

82. E.g., Garfinkle v. Superior Court, 21 Cal. 3d 268, 282, 578 P.2d 925, 934, 146 Cal. Rptr. 208, 217 (1978); Kruger v. Wells Fargo Bank, 11 Cal. 3d 352, 367 n.21, 521 P.2d 441, 450 n.21, 113 Cal. Rptr. 449, 458 n.21 (1974).

83. Connolly Dev., Inc. v. Snperior Court, 17 Cal. 3d 803, 811, 553 P.2d 637, 642, 132 Cal. Rptr. 477, 482 (1976), appeal dismissed, 429 U.S. 1056 (1977).

84. Kruger v. Wells Fargo Bank, 11 Cal. 3d 352, 359, 521 P.2d 441, 444, 113 Cal. Rptr. 449, 452 (1974).

85. 33 Cal. App. 3d 105, 108, 108 Cal. Rptr. 375, 377 (2d Dist. 1973). 
tion of property rendered the statute constitutional, but failed to consider the state action issue. ${ }^{86}$ In the other California decision addressing the constitutionality of lis pendens, Lake Tulloch Corp. v. Dingman, ${ }^{87}$ the Superior Court of Los Angeles County found the lis pendens statute to be unconstitutional, implicitly finding state action without discussing the issue. ${ }^{88}$ Moreover, in a slightly different context the California Supreme Court has lield that a lis pendens is not inerely a private act $^{89}$ and has no existence apart from the action in which it was filed. ${ }^{90}$

An analysis of the inost analogous California Supreme Court case also supports a finding of state action..$^{91}$ In Connolly Development, Inc. v. Superior Court, ${ }^{92}$ the supreme court observed that "[o]bviously all statutes . . . constitute state action of a sort, for the Legislature and not private persons enact legislation. ... [T] he question is whether the state, by reason of those laws, is so significantly involved in the taking that we may treat that taking as state action." 93 In Connolly, the court held that the impairment of an owner's property interest by the recordation of a mechanics' lien $^{94}$ constitutes state action. The court observed that the lien is subject to comprehensive statutory regulation and that it becomes effective only upon recordation with the county

86. Arguably, the court in Empfield assumed that state action is involved. In Chrysler Corp. v. Fedders Corp., No. 81-2128, slip op. at 23-24 (3d Cir. Jan. 25, 1982), the court noted that it was curious that most of the cases which have considered the constitutionality of lis pendens do not address the state action issue, and conclnded that the courts which find that lis pendens deny due process must assume that state action is involved.

87. No. WEC-27,140 (Super. Ct. June 1, 1973) (summarized in L.A. Daily J., June 5, 1973, at 1, col. 2), writ of mandate denied mem. sub nom. Dimgman v. Superior Court, 2 CIV 42,438 (Cal. Ct. App. 2d Dist. July 17, 1973).

88. Chrysler Corp. v. Fedders Corp., No. 81-2128, slip op. at 24 (3d Cir. Jan. 25, 1982); Note, Does California's Statutory Lis Pendens Violate Procedural Due Process?, 6 PAC. L.J. 62, 64 (1975).

89. Albertson v. Raboff, 46 Cal. 2d 375, 380, 295 P.2d 405, 409 (1956); cf. Ahmanson Bank \& Trust Co. v. Tepper, 269 Cal. App. 2d 333, 342, 74 Cal. Rptr. 774, 781 (2d Dist. 1969) (lis pendens is a "republication of the pleadings"). Albertson held that a lis pendens is a publication made in a judicial proceeding which, by virtue of CAL. CIv. CoDE $\$ 47(2)$ (West Supp. 1981), cannot be a basis for a slander of title action. See also 50 AM. JuR. 2D Libel and Slander $\$ 547$ (1970); (citing Albertson for the proposition that a lis pendens is absolutely privileged). A prior court of appeal ruling that a lis pendens is a "private act undertaken . . . for the purpose of calling to the attention to all the world the pendency of hitigation," West Inv. Co. v. Moorhead, 120 Cal. App. 2d 837, 840, 262 P.2d 322, 324 (2d Dist. 1953), was overruled by Albertson, 46 Cal. 2d at 380, 295 P.2d at 409.

90. $46 \mathrm{Cal}, 2 \mathrm{~d}$ at 379,295 P.2d at 408 .

91. It is possible that the definition of state action used by the California Supreme Court is broader than the definition used in federal constitutional cases. See Gay Law Students Ass'n v. Pacific Tel. \& Tel. Co., 24 Cal. 3d 458, 473 \& n.9, 595 P.2d 592, 601 \& n.9, 156 Cal. Rptr. 14, 23 \& n.9 (1979) (equal protection).

92. 17 Cal. 3d 803, 553 P.2d 637, 132 Cal. Rptr. 477 (1976), appeal dismissed, 429 U.S. 1056 (1977).

93. Id. at 814 n.10, 553 P.2d at 644 n.10, 132 Cal. Rptr. at 484 n.10.

94. Cal. Const. art. XX, § 15; CaL. Civ. Code $\$ \$ 3082-3153$ (West 1973 \& Supp. 1982). 
recorder, an official of the state..$^{95}$ Furthermore, the lien can be enforced only by resort to the state courts, as opposed to a private remedy the legahity of which was recognized by statute. ${ }^{96}$ Similarly, recordation of a lis pendens is governed by detailed statutory provisions, ${ }^{97}$ and becomes effective only upon recordation with the county recorder. ${ }^{98}$ Furthermore, the his pendens may only be filed in connection with a proceedimg im court. ${ }^{99}$

A less relevant case, which must be considered, is Garfinkle v. Superior Court. ${ }^{100}$ Garfinkle upheld a nonjudicial foreclosure procedure which required recordation of a default notice which binds subsequent purchasers and lienors. ${ }^{101}$ Garfinkle should not be controlling since the default notice in Garfinkle is much less similar to a his pendens than was the mechanics' hen in Connolly. By definition, a nonjudicial foreclosure does not involve the courts. The remedy involved, the power of sale, is authorized solely by the private contract between the lender and the trustor. ${ }^{102}$ The lis pendens, in contrast, is a creature of the judicial system; it has no existence apart froin a judicial proceeding. ${ }^{103}$ State action is therefore involved im the lis pendens procedure smce the deprivation of property, if any, is effected through court process. ${ }^{104}$ This is true even if the deprivation is temporary. ${ }^{105}$ The lis pendens is therefore more closely related to the Connolly mechanics" lien which "can be enforced only by resort to the state courts." 106 Thus, lis pendens recordation mvolves state action under the California Constitution.

The issuance of a his pendens may also constitute state action under the fourteenth amendment of the United States Constitution. A lis pendens is a court process ${ }^{107}$ inseparable from the judicial determi-

95. 17 Cal. 3d at 815, 553 P.2d at 645, 132 Cal. Rptr. at 485.

96. Id. at $815-16,553$ P.2d at $645-46,132$ Cal. Rptr. at $485-86$.

97. CAL. CIv. Proc. Code $\$ \S 409-409.6$ (West Supp. 1981).

98. Id. $\S 409$.

99. Id.

100. 21 Cal. 3d 268, 578 P.2d 925, 146 Cal. Rptr. 208 (1978).

101. See Cal. Civ. Code $\$ 2924$ (West 1974).

102. 21 Cal. 3d at 277 \& n.14, 578 P.2d at 931 \& n.14, 146 Cal. Rptr. at 214 \& n.14; see CAL. Civ. CoDE $\$ 2924$ (West 1974).

103. See supra note 89.

104. Adams v. Departmeut of Motor Vehicles, 11 Cal. 3d 146, 152, 520 P.2d 961, 964, 113 Cal. Rptr. 145, 148 (1974) (dictum); see Flagg Bros., Inc. v. Brooks, 436 U.S. 149, 157 (1978).

105. North Ga. Finishing, Inc. v. Di-Chem, Inc., 419 U.S. 601, 606 (1975); Blair v. Pitchess, 5 Cal. 3d 258, 277-78, 486 P.2d 1242, 1256, 96 Cal. Rptr. 42, 56 (1971).

106. Connolly, $17 \mathrm{Cal}$. 3d at $815,553 \mathrm{P} .2 \mathrm{~d}$ at $645,132 \mathrm{Cal}$. Rptr. at 485 (footnote omitted).

107. One California case held that the filing of a lis pendens is absolutely privileged, and thus cannot become the basis for an action for abuse of process. Woodcourt II Ltd. v. McDonald Co., 119 Cal. App. 3d 245, 249-50, 173 Cal. Rptr. 836, 838-39 (2d Dist. 1981). The Woodcourt court went on in dictum to conclude that the recording of a lis pendeus is not process in the sense of "abuse of process" referring to process as a means whereby a court compels a compliance with its demands. Id. at 251-52, 173 Cal. Rptr. at 839-40. In contrast, Earp v. Nobmann held that a hs 
nation of title to or right of possession of realty. ${ }^{108}$ As shown in the next section, the practical result of the recordation of a lis pendens is the temporary mahenability of the affected real estate. ${ }^{109}$ Therefore, fourteenth amendment state action is shown because the property's ahenability is impaired under the authority of the court, as a result of the recordation of the lis pendens. ${ }^{110}$ While it is true that Flagg Bros., Inc. v. Brooks ${ }^{111}$ narrowed the scope of what constitutes state action with regard to the deprivation of property, the Court stated that state action was present when a debtor was deprived of a property right under state law, under the authority of a state court. ${ }^{112} \mathrm{~A}$ lis pendens also deprives the property owner of a property riglit (alienability), under California law, under the authority of a California court, and thus state action under the fourteenth amendment inay be present.

\section{B. Deprivation}

A deprivation requiring procedural due process encompasses any significant deprivation of a property interest, i.e., a deprivation that cannot be dismissed as "de minimis" or "insubstantial." 113 Although most cases finding constitutional deprivation have only dealt with deprivations of the use and enjoyinent of property ratler than its ahenability, ${ }^{114}$ other cases have recognized that alienability is a significant incident of property ownership. ${ }^{115}$ This Section argues that the result of recording a notice of lis pendens is a temporary impairment of the marketability of property, a deprivation of such nature and duration that procedural due process is required by the California Constitution and possibly by the United States Constitution as well.

Recording a his pendens amounts to a significant deprivation of property by impairing the owner's right to alienate the property. ${ }^{116}$ The owner is not deprived of the possession and use of his property; neither is the owner prevented front selling it. A his pendens on the

pendens is absolutely privileged in an action for disparagenent of title but indicated that the plaintiff might have been successful had he alleged and proved abuse of process. 122 Cal. App. $3 \mathrm{~d}$ 270, 281-82, 175 Cal. Rptr. 767, 773-74 (3d Dist. 1981).

108. See supra note 89.

109. See infra text accompanying notes 116-23.

110. Flagg Bros., Inc. v. Brooks, 436 U.S. 149, 160-61 n.10 (1978).

111. 436 U.S. 149 (1978).

112. Id. at $160-61$ n.10.

113. Randone v. Appellate Dep't, 5 Cal. 3d 536, 552, 488 P.2d 13, 23, 96 Cal. Rptr. 709, 719 (1971), cert. denied, 407 U.S. 924 (1972).

114. See, e.g., Fuentes v. Shevin, 407 U.S. 67 (1972); Beaudreau v. Superior Court, 14 Cal. 3d 448, 535 P.2d 713, 121 Cal. Rptr. 585 (1975).

115. See, e.g., Shelley v. Kraemer, 334 U.S. 1, 10 (1948); Buchanan v. Warley, 245 U.S. 60, 74 (1917).

116. Review of Selected 1976 California Legislation, 8 PAC. L.J. 165, 454 (1977); Comment, supra note 18, at 108-09. 
record, however, has the practical effect of preventing the owner from conveying a marketable title. ${ }^{117}$ The notice makes the title to property virtually uninsurable. ${ }^{118}$ Lenders will not nnake loans secured by property with uninsurable title, ${ }^{119}$ and any buyers who might be willing to buy subject to the result of the underlying action would require a "sacrifice" price as coinpensation for the risk. ${ }^{120}$ Furthermore, although any deprivation caused by the lis pendens will end when judginent in the underlying action has becoine final, ${ }^{121}$ a significant amount of time will pass between recordation of the lis pendens and entry of judgment at the trial level, ${ }^{122}$ to which another year or two can be added if the judgment is appealed. ${ }^{123}$ In Califorma, Connolly Development, Inc. $v$. Superior Court ${ }^{124}$ appears to be the most persuasive authority on whether this type of deprivation of property amounts to a constitutional deprivation. ${ }^{125}$ It held that California's mechanics' lien statute

117. Calif. Dep't of Real Estate, Reference Book 92 (1979-1980 ed.).

118. "Title companies ordinarily refuse to insure when it is apparent that litigation will be necessary to prove clear title." California Continuing Education of the Bar, California Real Estate Sales Transactions 612 (1967). Purchasers often agree to buy only if the title is marketable, depending on the title insurance report for this determination. Johnstone, Title Insurance, 66 YALE L.J. 492, 494 (1957).

119. California Continuing Education of the Bar, supra note 118, at 607.

120. See supra note 2.

121. See Garcia v. Pinhero, 22 Cal. App. 2d 194, 196, 70 P.2d 675, 676 (4th Dist. 1937); CAl. Crv. Proc. CODE $\S 1049$ (West 1980). Its practical effect, at least under the cnrrent statutory scheme, does not end when a lis pendens expungement order is entered. See infra text accompanying notes 161-62.

122. See supra note 14.

123. California Courts of Appeal-Median Time in Months from Notice of Appeal to Filing of Opinion in Civil Cases

(Quarter Ending June 30, 1980)

District I

Division 1 .................22

Division 2 .................. 22

Division 3 , ..................... 16

Division 4 .................. 17

District II

Division 1 .................. 15

Division 2 ................... 16

Division 3 ................... 15

Division 4 .................... 17
District II

Division 5 ................. 18

District III $\ldots \ldots \ldots \ldots \ldots \ldots \ldots \ldots 15$

District IV

Division 1 ................. 12

Division 2 ................. 11

District $\mathrm{V} \ldots \ldots \ldots \ldots \ldots \ldots \ldots \ldots, 18$

Source: Judicial Council of California, supra note 14, at 84.

124. 17 Cal. 3d 803, 553 P.2d 637, 132 Cal. Rptr. 477 (1976), appeal dismissed, 429 U.S. 1056 (1977).

125. The federal courts and the California courts have apparently parted company on this point. The United States Supreme Court was recently confronted with three direct appeals from cases upholding the constitutionality of mechanies' lien statutes. In two cases, the Court dismissed the appeals for want of a substantial federal question: in Connolly, which found a deprivation but concluded that due process was satisfied, and in Carl A. Morse, Inc. v. Rentar Indus. Dev. Corp., 56 A.D.2d 30, 36, 391 N.Y.S.2d 425, 430 (1977), affd mem, 43 N.Y.2d 952, 375 N.E.2d 409, 404 N.Y.S.2d 343, appeal dismissed, 439 U.S. 804 (1978), which did not find a deprivation and also 
operated to deprive owners of significant property interests, since

although the imposition of a mechanics' hen does not deprive the owner of the interim use of his property, it may severely hamper his ability to sell or encumber that property. Subsequent purchasers whose title will be subject to the hen may be unwilling to purchase a lawsuit with the land; lenders may refuse a loan on property subject to lien claims; the owner inay in some cases be forced to pay a possibly invalid lien in order to clear title to his property in time for a pending transaction to be consummated. ${ }^{126}$

These concerns about the effect of a inechanics' hen apply equally to the effect of a his pendens. Thus, the reasoning in Connolly supports treating a lis pendens as a significant deprivation of property.

In fact, the deprivation of property interests caused by a lis pendens is much inore serious an impairment than that caused by a inechanics' hen. Mechanics' liens are for a certain antount of money that can be paid by the owner or any subsequent purchaser to clear the title; in fact, a property owner can release a lien by recording a payment bond equal to one and one half times the anount of the claim. ${ }^{127}$ $A$ lis pendens, on the other hand, is recorded in an action "affectimg the title to or right to possession of real property,"128 such as a suit seeking specific performance of a contract to convey land, which ordinarily cannot be satisfied with anything but the property. ${ }^{129}$ It is no wonder that a his pendens cannot be expunged, even if the owner posts an undertaking adequate to secure payment of "all danuages which [the plaintiff] may incur if the notice is expunged and the [owner] does not prevail," unless the trial court affirmatively finds "that adequate relief can be secured to the [planitiff] by the giving of such undertaking."130

The conclusion that a lis pendens causes a significant deprivation of property may not be countered validly by dictum in Empfield $v$. Superior Court. ${ }^{131}$ Empfield did conclude that the lis pendens statutes do

concluded that procedural due process was satisfied. In the third case, the Court summarily affirmed the judgment of a three-judge district court sustaining the validity of Arizona's mechanics' lien statutes on the ground that there was no deprivation of property. Spielman-Fond, Inc. v. Hanson's Inc., 379 F. Supp. 997, 999 (D. Ariz. 1973) (per curiani), aff'd mem., 417 U.S. 901 (1974). Such summary dispositions are considered to be on the merits and binding on federal courts, Hicks v. Miranda, 422 U.S. 332, 344-45 (1975), but ouly as to the result reached and not as to the reasoning. Fusari v. Steimberg, 419 U.S. 379, 391 (1975) (Burger, C.J., concurring).

126. $17 \mathrm{Cal} .3 \mathrm{~d}$ at $812,553 \mathrm{P} .2 \mathrm{~d}$ at $643,132 \mathrm{Cal}$. Rptr. at 483 (footnote omitted) (four justices); accord id. at 839, 553 P.2d at 661, 132 Cal. Rptr. at 501 (Richardson, J., dissenting) (three justices).

127. CaL. Crv. Code $\$ 3143$ (West 1974).

128. Cal. Crv. Proc. Code $\$ 409$ (West 1973).

129. Remmers v. Ciciliot, 59 Cal. App. 2d 113, 119-20, 138 P.2d 306, 310 (2d Dist. 1943); CAL. Crv. CoDE $\$ 3387$ (West 1970).

130. Cal. Crv. Proc. Code $\$ 409.2$ (West Supp. 1981).

131. 33 Cal. App. 3d 105, 108 Cal. Rptr. 375 (2d Dist. 1973). 
not work a constitutionally significant deprivation. ${ }^{132}$ Empfield's dictum was imphicitly disapproved by Connolly, however, since Connolly cited Empfield for the proposition that the impairment of ahenability occasioned by the recording of a mechanics' lien is not a constitutional deprivation, but then held otherwise. ${ }^{133}$

\section{What Process Is Due}

The final step in a due process analysis of the Cahfornia lis pendens statute is determining whether there are procedural safeguards that reasonably accommodate the competing interests of the opposing parties and the state. ${ }^{134}$ This involves an analysis of three sets of interests: the owner's interest, the plaintiff's interest, and the state's interest. Analysis reveals that the statutory procedural safeguards are inadequate.

Turning first to the property owner's interest, the effect of a hs pendens on the owner varies depending on his plans for the property. If the owner does not plan to sell or encumber the property, he does not suffer at all, ${ }^{135}$ and there are no difficulties with the present procedure allowing the his pendens to remain on record. Once the property owner has coine to court to expunge the lis pendens, however, it is probably safe to assume that the lis pendens on record is interfering with his plans for the realty; that is, the owner has suffered a deprivation of property and has an interest in not having the deprivation continued.

The plaintiff's interest in the inatter is assurance that his claim to the property is not frustrated by a prejudgment transfer of that property. In some cases, such as those seeking specific perforniance of an agreement to transfer real property, uniqueness of the land inakes that assurance necessary. ${ }^{136}$ Lastly, the state has an interest in maintaining an orderly recordimg and notice system for transactions in real property, ${ }^{137}$ and in having a specified procedure to determine the rights of third party purchasers of property that is the subjcct of litigation. ${ }^{138}$

The current lis pendens expungement procedure does provide the

132. Id. at 108, 108 Cal. Rptr. at 377 (dictum). But see Lake Tulloch Corp. v. Dingman, No. WEC-27,140 (Super. Ct. June 1, 1973), petition for writ of mandate denied mem. sub nom. Dingman v. Superior Court, No. 2 Civ. 42,430 (Cal. Ct. App. 2d Dist. July 17, 1973).

133. $17 \mathrm{Cal}$. 3d at 811-12 \& n.4, 553 P.2d at $642-43$ \& n.4, 132 Cal. Rptr. at $482-83$ \& n.4.

134. Mathews v. Eldridge, 424 U.S. 319, 335 (1976); People v. Ramirez, 25 Cal. 3d 260, 269, 599 P.2d 622, 627, 158 Cal. Rptr. 316, 321 (1979); Connolly Dev., Inc. v. Superior Court, 17 Cal. 3d 803, 806-07, 553 P.2d 637, 639, 132 Cal. Rptr. 477, 479 (1976), appeal dismissed, 429 U.S. 1056 (1977).

135. Chrysler Corp. v. Fedders Corp., No. 81-2128, slip op. at 26 (3d Cir. Jan. 25, 1982).

136. See CAL. Crv. Code $\$ 3387$ (West 1970).

137. Empfield v. Superior Court, 33 Cal. App. 3d 105, 108, 108 Cal. Rptr. 375, 377 (2d Dist. 1973).

138. Chrysler Corp. v. Fedders Corp., No. 81-2128, slip op. at 27 (3d Cir. Jan. 25, 1982). 
plaintiff some protection. First, a his pendens may be filed only when the pending action affects title to or the right of possession of real estate, ${ }^{139}$ and the notice will be expunged if the recording party cannot show that the underlying action does not measure up to at least that standard. ${ }^{140}$ In addition, the notice may be expunged if the owner posts a sufficient undertaking to assure adequate retief for the plaimtiff. ${ }^{141}$ Finally, tort remedies are available to redress a property owner against wholn a frivolous claim on the property was asserted, such as an action for inalicious prosecution. ${ }^{142}$

None of these reinedies, however, adequately protects the property owner against frivolous or meritless deprivation. First, an expungement cannot be obtamed simply by postimg an undertaking. The trial judge must first find that adequate relief can be secured to the plaimtiff by the posting of a bond, which means that the party moving for expungeinent inust overcome a statutory presumption to the contrary. ${ }^{143}$ Furthermore, even if the owner is allowed to post a bond, he is merely given a choice between two deprivations. Bemg required to post a bond has also been held to involve constitutionally significant deprivation of property. ${ }^{144}$

Second, the tort reinedies available to the owner are nnsatisfactory as they require him to bear the expense and delay of a subsequent court action. In addition, the owner will probably have to prove that the former action was prosecuted for an improper purpose and without reasonable cause, a most onerous burden. ${ }^{145}$

Finally, the absence of a hearing to guard against erroneous deprivation due to a hs pendens evidences a lack of adequate procedural safeguards in itself. Absent a severe impairment to either the plaintiff's or the state's interests justifying resort to summary procedures, the courts have required soine sort of hearing to guard against erroneous deprivation. ${ }^{146}$ A hearing requireinent will not severely impair plaintiff's interest, since expungement will be granted only when it appears

139. Cal. Civ. Proc. Code $\S 409$ (West 1973).

140. Id. $\$ 409.1$ (a) (West Supp. 1981).

141. Id. $\$ 409.2$. In upholding the sequestration procedure in Mitchell v. W.T. Grant Co., 416 U.S. 600 (1974), the Supreme Court noted that the debtor was able to dissolve the sequestration writ by posting a bond. Id. at 608 .

142. Albertson v. Raboff, 46 Cal. 2d 375, 382-84, 295 P.2d 405, 410-12 (1956).

143. See supra note 27 and accompanying text.

144. Bcaudreau v. Superior Court, 14 Cal. 3d 448, 456, 535 P.2d 713, 717, 121 Cal. Rptr. 585, 589 (1975); Brooks v. Sinall Claims Court, 8 Cal. 3d 661, 667, 504 P.2d 1249, 1253, 105 Cal. Rptr. 785, 789 (1973).

145. See supra note 27 and accompanying text.

146. North Ga. Finishing, Inc. v. Di-Chem, Inc., 419 U.S. 601, 606 (1975); Kash Enters., Inc. v. City of Los Angeles, 19 Cal. 3d 294, 308, 562 P.2d 1302, 1310-11, 138 Cal. Rptr. 53, 61-62 (1977). 
that the lis pendens would cause an erroneous deprivation. Neither will the state's interest be affected. The requirement of a hearing will not adversely affect the state's recording system if the lis pendens is allowed to remain on record until the learing is held. Therefore, since no extraordimary circumstances obviate the need for a hearing, a hearing is constitutionally required. The learing must provide the individual subjected to the deprivation an opportunity to present his side ${ }^{147}$ and it therefore inust address the validity of the underlying claim. ${ }^{148}$ Hence, the present procedure, which only considers the merits of the underlying claim in the inost rudimentary fashion, and then looks to the subjective intent of the plaintiff, is constitutionally inadequate.

\section{IV \\ A Proposed Lis Pendens Expungement Statute}

To meet the requirements of procedural due process, a new lis pendens expungeinent statute is needed. This Note proposes a revised section 409.1 which would remedy the constitutional problems raised by the present lis pendens statute and would give expungement the desired practical effect of removing the cloud on title caused by the lis pendens.

The proposed statute provides:

\$ 409.1 Expunging lis pendens; luearing; recordation of order; effect

(a) At any time after notice of pendency of an action has been recorded pursuant to section 409 or other law, the court in which the action is pending shall, upon motion of a party to the action supported by affidavit, order that the notice be expunged, unless the party filing the notice shows to the satisfaction of the court, by a preponderance of the evidence, that:

(1) the action affects title to or right of possession of the real property described in the notice; ${ }^{149}$

(2) the claim upon which the notice is based is probably valid; ${ }^{150}$ and

(3) if the underlying claim seeks specific performance of an agreement to transfer real property, the agreed

147. Goss v. Lopez, 419 U.S. 565, 581 (1975); Beaudreau v. Superior Court, 14 Cal. 3d 448, 460, 535 P.2d 713, 721, 121 Cal. Rptr. 585, 593 (1975); see Van Atta v. Scott, 27 Cal. 3d 424, 434, 613 P.2d 210, 214, 166 Cal. Rptr. 149, 153 (1980).

148. North Ga. Finishing, Inc. v. Di-Chem, Inc., 419 U.S. 601, 607 (1975); Bell v. Burson, 402 U.S. 535, 540 (1971); Kash Enters., Inc. v. City of Los Angeles, 19 Cal. 3d 294, 309, 562 P.2d 1302, 1311, 138 Cal. Rptr. 53, 62 (1977); Beaudreau v. Superior Court, 14 Cal. 3d 448, 459, 535 P.2d 713, 720, 121 Cal. Rptr. 585, 592 (1975); Randone v. Appellate Dep't, 5 Cal. 3d 536, 562, 488 P.2d 13, 30-31, 96 Cal. Rptr. 709, 726-27 (1971), cert. denied, 407 U.S. 924 (1972).

149. Subdivisions (a) and (a)(1) represent no change from existing law.

150. Subdivision (a)(2) is based on language in CAL. C1v. Proc. Code $\$ \S 484.090$ (a)(2), 512.040(b) (West Supp. 1981). 
counterperformance has been substantially performed or its concurrent or future performance is assured..$^{151}$

(b) Notice of motion to expunge shall be served not less than twenty days prior to the hearing. ${ }^{152}$

(c) The court's determination shall be made on the basis of the pleadings and other papers in the record; but, upon good cause shown, the court may receive and consider at the hearing additional evidence, oral or documentary, and additional points and authorities, or it may continue the hearing for the production of such additional evidence or points and authorities. ${ }^{153}$

(d) No findings shall be required in a hearing conducted pursuant to this section. No determination in the hearing under this section shall be res judicata with respect to any right of action by the recording party against either principal or surety on any undertaking or bond required or permitted to be given under this section, or with respect to any right of action against any party personally liable to the recording party. ${ }^{154}$ (e) Upon recordation of a certified copy of the order expunging a notice of pendency in the office of the county recorder in which the notice of pendency of action was recorded, any purchaser or encumbrancer may thereafter deal with the property described in such notice free and clear of the effect of the action whether or not he has actual notice of the pendency of the action. ${ }^{155}$

(f) The court, as a condition of granting or denying the motion to expunge, may require that the party prevailing upon such motion give the other party an undertaking of such nature, and in such amount as shall be fixed by the court, such undertaking to be to the effect that such prevailing party will indemnify the other party for all damages which he may incur if he ultimately prevails in the action. ${ }^{156}$

This proposal differs from the existing section 409.1 in three respects. First, it requires that the party filing the notice show that his action is probably valid, rather than showing that it was prosecuted or commenced in good faith. Second, the party filing the lis pendens, if requestimg specific performance from the court, must prove that he is capable of performing his portion of the contract. Third, the effect of the lis pendens is changed to allow the property owner to convey an insurable title to his property if the notice is expunged.

To fulfill the requirements of due process under the California

151. Subdivision (a)(3) is based on language in CAL. CIv. CODE \& 3386(b) (West 1970).

152. Subdivision (b) represents no change from existing law.

153. Subdivision (c) is based on language in CAL. CIv. Proc. Code $\$ 512.050$ (West Supp. 1981).

154. Subdivision (d) is based on language in CAL. CIv. CoDe $\$ \S 3203,3205$ (West Supp. 1981).

155. Subdivision (e) is based on language in Act of July 1, 1968, ch. 815, § 2, $1968 \mathrm{Cal}$. Stat. $1571,1572$.

156. Subdivision (f) represents no change froin existing law. 
Constitution, the lis pendens expungement procedure must involve some consideration of the merits of the underlymg action. ${ }^{157}$ The proposed statute requires a showing of the probable validity of the underlymg claim, which would eliminate the constitutional difficulties with the existing hs pendens scheme. To prevent the expungement hearing from expanding into a "minitrial," the statute also explicitly provides that the hearing shall have no res judicata effect on the underlying action or on any collateral action to recover on a security bond, and it provides for oral proof or points and authorities only if the judge deems it necessary. Consequently, smce the expungement hearing is only a preliminary determination of the validity of the action, the court may, in its discretion, require the party winning the expungement motion to post an undertaking for the protection of the other party, as provided $\mathrm{m}$ the present statute.

The proposed statute also imposes the burden of proof on the recording party to show probable validity by a preponderance of the evidence. A "preponderance of the evidence" means such evidence which, when weighed with that opposed to it, has more convincimg force. ${ }^{158}$ "Probable validity" of a claim means that it is more likely than not that the plaintiff will obtain a judgment against the defendant on that claim. ${ }^{159}$ The proposed standard is met relatively easily, reflectmg the fact that it is harder to prove the probable validity of the underlying action, an objective standard, than it is to prove good faith, a subjective standard. Such a low standard is posited because the intention of the proposed statute is to prevent the recordation of unwarranted notices of pendency while allowing legitimate notices to remain on the record. Presumably, a party legitimately recording a lis pendens can generally demonstrate probable validity by a preponderance of the evidence.

The proposed statute also requires the party filing the lis pendens, if he is requesting an ultimate remedy of specific perforinance in the action, to show at the hearing that he will be able to undertake his agreed upon counterperfornance. This provision ensures that the property owner is not prevented froin selling the property to another when the plaintiff, even if he ultimately prevailed, would be unable to carry out his end of the agreement. ${ }^{160}$

Finally, the proposed statute replaces the current provision de-

157. See supra text accompanying notes 131-45.

158. See, e.g., People v. Miller, 171 Cal. 649, 652-54, 154 P. 468, 470 (1916); In re Corey, 230 Cal. App. 2d 813, 823, 41 Cal. Rptr. 379, 385 (1st Dist. 1964).

159. CAL. Crv. Proc. Code $\$ 511.090$ (West Supp. 1981).

160. Restatement (SECOND) of Contracts $\$ 363$ comment a (1979); Comment, Mutuality of Remedy-Demise of an Ancient Proverb in Califormia, 1 PAC. L.J. 654, 669 (1970). 
lineatimg the effect of an expungement order with the language used in the 1968 version of section 409.2. This change is required if an expungement order is to have any practical effect. The current statute provides that a purchaser of property on which an expunged lis pendens is placed will still take subject to the result of the underlying action if by some happenstance he had actual notice of the action from some source other than the chain of title; it limits any subsequent purchaser's or encumbrancer's protection by providing that only the expungement order or "any information derived therefrom" shall not constitute actual notice. ${ }^{161}$ This nebulous standard is too risky for title insurance compamies, who generally refuse to insure the title of property subject to an expunged lis pendens under the present section 409.1 but who in the past had insured property on which a lis pendens had been expunged pursuant to the 1968 version of section 409.2 . $^{162}$ Thus, the proposed language would probably have the effect of allowing potential purchasers of property on which an expunged hs pendens has been recorded to buy title imsurance policies. This effect would equalize the marketability of property on which a lis pendens and an expungement order have been recorded with that of property on which no lis pendens has been recorded.

\section{CONCLUSION}

The lis pendens expungement statute has been subject to criticism and confusion since it was first implemented in 1968. While the courts and commentators agree that an expungement process is necessary to prevent the use of lis pendens as a "practical blackjack," the present expungement procedure causes a deprivation of a significant property interest without due process of law under the California Constitution. The new section 409.1 proposed by this Note would comply with due process requirements while still protecting the plaintiff and preventing his pendens recorded in bad faith. In addition, the new statute would probably assure that an expungement would have the practical effect of restoring the alienability of the affected property.

Valerie L. Castle*

161. CAL. Civ. Proc. Code $\S 409.1$ (West Supp. 1981).

162. Memorandum of Robert C. Webster, supra note 29; Letter from Richard M. Mark, Esq. to Sen. Anthony Beilenson (Feb. 14, 1974) (on file with the California Law Review).

* B.A. 1980, University of California, Riverside; third-year student, Boalt Hall School of Law, University of California, Berkeley. 